上咽頭癌と頸部結核性リンパ節炎の合併症例

\author{
金子 卓爾・赤尾 一郎・岩武 博也 \\ 加藤 功・高木 正之*

\section{Two Cases with Metastatic Cervical Lymph Nodes from Nasopharyngeal Carcinoma Simultaneously Showing Tuberculous Caseosa}

\author{
Takuji Kaneko, Ichiro Akao, Hiroya Iwatake, \\ Isao Kato and Masayuki Takagi \\ (School of Medicine, St. Marianna University)
}

\begin{abstract}
We had encountered two men, 51-year and 35-year-old, with nasopharngeal carcinoma. These patients showed nasopharyngeal tumor and metastatic lymph nodes in the neck. After chemotherapy followed by radiation, bilateral neck dissection was performed under general anesthesia.

Poorly differentiated carcinoma was diagnosed histologically in both patients, however, resected of neck lymph nodes showed caseating granuloma suggesting tuberculous. Thus, it was suggested that tuberculous lymph nodes might be caused by decreased immunological competence due to nasopharyngeal carcinoma.

There have been few cases with lymphadenitis which have demonstrated both cancer cells and tuberculous caseosa.

We discuss the mechanism based on previous reports.
\end{abstract}

Key words : metastatic cervical lymph node, nasopharyngeal carcinoma, tuberculous cervical lymphadenitis

はじめに

上咽頭癌は，頭頸部悪性腫瘍の中でも治療成績が悪く， その発症には患者の免疫能低下が関与していると考えら れている腫瘍である1). 現在当科においては, 化学療法 と放射線の併用療法を主体に治療を行い, 頸部リンパ節 転移を認める場合, 頸部郭清術を施行している. 今回わ れわれは, 頸部リンパ節内に結核の併発が認められた 2 例の上咽頭癌頸部リンパ節転移症例を経験したので, 若 干の文献的考察とともに報告する.

\section{症例}

症例 $1: 51$ 歳, 男性.

主訴：左頸部腫瘤.

既往歴・家族歴：特記すべきことなし。

現病歴 : 平成 5 年 5 月上旬より左胸鎖乳突節前縁に腫 瘤を自覚し, その後咽頭痛や腫瘤の疼痛・増大を認めた. このため近医を受診し，平成 5 年 5 月 23 日当科に紹介さ れた。

初診時所見 : 触診上, 左胸鎖乳突筋前縁に半球状 $5 \times 4$ $\mathrm{cm}$ の表面平滑, 可動性不良, 弾性硬, 王痛を伴う腫瘤

聖マリアンナ医科大学耳鼻咽喉科学教室

* 聖マリアンナ医科大学第 1 病理学教室 
を認めた。また上咽頭の内視鏡所見では上咽頭左側壁か ら左後口蓋弓にかけて表面不整な腫脹を認めた。

検查所見: 尿, 血液一般, 生化学検査では異常所見を 認めなかった。血沈時間値 $9 \mathrm{~mm}, 2$ 時間値 $23 \mathrm{~mm}$ 之軽 度九進している他, 脳神経症状や胸部単純 X線では活動 性特よび陳旧性の結核病変を疑わせる石灰化等の異常な 所見を認めなかった．梅毒血清反応(一)、ッベルクリン 反応 $26 \times 25 \mathrm{~mm}$ と陽性であった。 CD 4/8 比は 1.5 と低 下していた。 上咽頭・頸部の CT スキャンでは左耳管隆 起，上咽頭後壁から中咽頭にかけて表面不整なアデノイ ド様腫瘤, 特よび左頸動脈に沿って多発性で境界明膫な 腫瘤が認められた(図1)。また画像による全身検索では 遠隔転移は認められなかった。喀痰, 尿の細菌検査は陰 性であった。

経過特よび治療: 強く悪性腫瘍を疑い上咽頭より生検 を施行した結果, 低分化型扁平上皮癌の病理診断が得ら れ, TNM 分類にて上咽頭癌 $\mathrm{T} 2 \mathrm{~N} 2 \mathrm{bM} 0$ と診断された。 上咽頭癌に対して neo-adjuvant chemotherapy として PTP (CDDP $60 \mathrm{mg} / \mathrm{m}^{2}$, THP-ADM $30 \mathrm{mg} / \mathrm{m}^{2}, \quad$ PEP $20 \mathrm{mg} /$ body) 療法を 2 クール行った.さらに化学療法終 了後, 右頸部リンパ節に対して根治的郭清術を施行した。
術後の病理検査で右下内深頸リンパ節に, 癌転移巣と乾 酪壊死物質の周りに類上皮細胞が認められる乾酪性肉芽 腫が混在する病理所見を認めたため, 典型的な頸部結核 性リンパ節炎と診断された(図 2). 術後は, 抗結核阂と して INH とRFPの 2 剂を併用した。また原発の上咽 頭癌に対して, 総線量 $60 \mathrm{~Gy}$ の放射線照射を施行した.

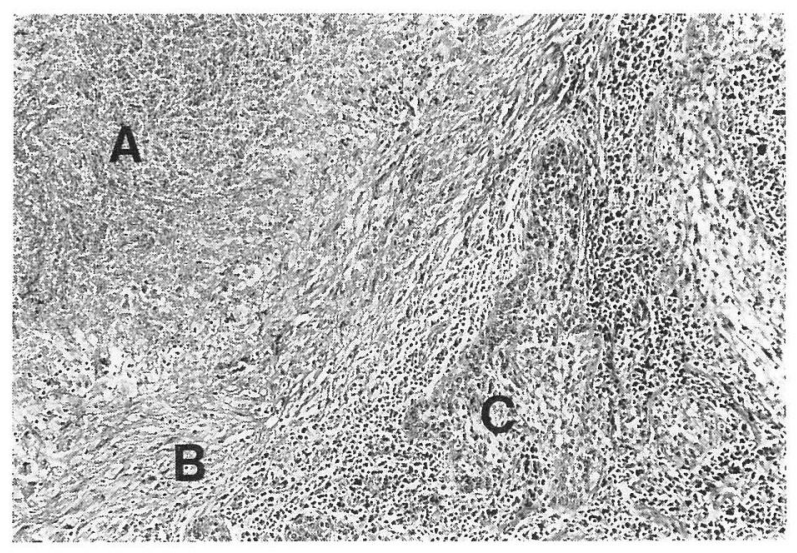

図 2 症例 1 の病理組織学的所見 $($ H.E. 染色 $\times 100)$ A. 乾酪壊死 B. 類上皮細胞 C. 癌胞栄

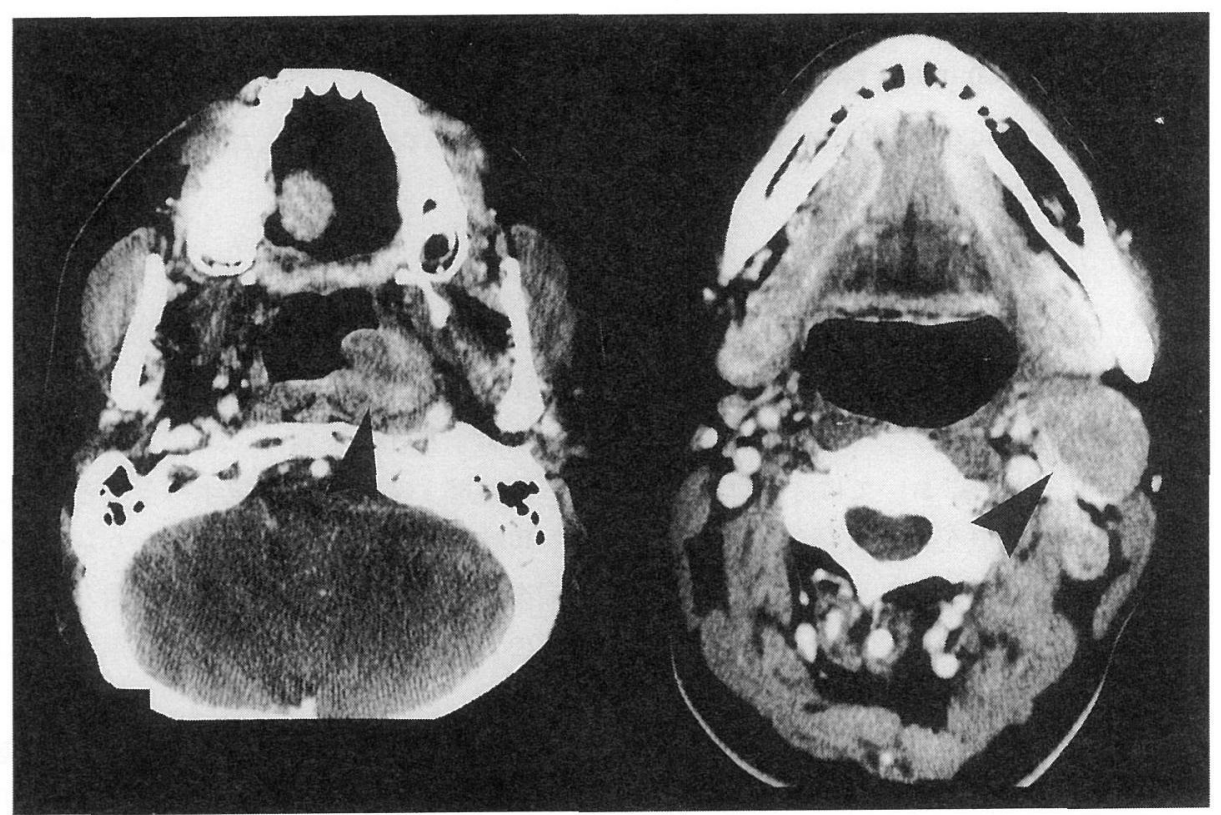

図 1 症例 1 の頸部 CT スキャン

左：ローゼンミューラー窩に造影剂で不整に増強する腫瘍を認める(䅡).

右：左頸部に $3.0 \times 2.0 \mathrm{~cm}$ 大の造影効果のあるリンパ節を認める(矢頭). 
2 カ月の経過観察の後に, 上咽頭癌に関しては化学療法 の追加治療を行ったが，頸部結核性りンパ節炎について は平成 7 年 4 月まで再発もなく順調に経過している.

症例 2. 35歳, 男性.

主訴 : 両側頸部腫脹.

既往歴 : 平成 2 年脂肪肝.

現病歴: 平成 4 年 6 月より微熱を繰り返していたが放 置していた。同年12月両側頸部のリンパ節腫脹に気づき， 近医受診し内服剂にて経過をみるも改善せず平成 5 年 1

月 7 日当科を受診した。

初䛦時所見：触䛦により両側頸部に右 $3.5 \times 3.5 \mathrm{~cm}$, 左 $6.0 \times 4.5 \mathrm{~cm}$ の表面不整, 可動性不良, 圧痛を伴弓 充実性の腫瘤を認めた。上咽頭の内視鏡では, 左上咽頭 から中咽頭に達する表面不整な腫脹を認めた。

検査所見：尿，血液一般，生化学検査では，白血球 $13,500 / \mathrm{mm}^{3}$, 血沈 1 時間值 $64 \mathrm{~mm}, 2$ 時間値 $90 \mathrm{~mm}$, CRP $5.8 \mathrm{mg} / \mathrm{dl}$ と六進していた. 脳神経症状を認めず, 胸部単純X線では活動性および陳旧性の結核病変を疑わ せる石灰化等の異常な所見を認めなかった，梅毒血清反 応 $($ 一), ツベルクリン反応 $22 \times 20 \mathrm{~mm}$ と陽性で, CD 4/8 值0.4と低下していた。 上咽頭・頸部 CT スキャンでは
左耳管隆起，咽頭側索から上咽頭後壁にいたる不整な腫 脹，抽よび多発性の腫瘤を両側頸部に認めた(図 3 )。を た ${ }^{67} \mathrm{Ga}$-citrate シンチグラフィーでは両側の頸部から鎖 骨上飞異常集積が認められた(図 4 )。その他画像による 全身検索を施行したが異常は認められなかった．喀痰， 尿の細菌検査では，一般細菌の文陽性であった。

経過抒よび治療：上咽頭および頸部リンパ節生検の結 果，低分化型扁平上皮癌の病理診断が得られ，TNM 分 類にて上咽頭癌 T $3 \mathrm{~N} 3 \mathrm{M} 0$ と診断した. neo-adjuvant chemotherapy とし PTP (CDDP $60 \mathrm{mg} / \mathrm{m}^{2}$, THP-ADM $30 \mathrm{mg} / \mathrm{m}^{2}$, PEP $20 \mathrm{mg} /$ body) 療法を 2 クール，年の後 総線量 40 Gy の放射線を照射施行するも効果を認めず, 他剂 (VP16 195 mg, MMC 7 mg) 併用した。化学療法 終了後に両側頸部リンパ節に対して郭清術(右根治的, 左保存的)を行った。術後の病理検査にて左上拉よび中 深頸りンパ節に広汎な乾酪巣を有しながら散在性に癌病 巣が混在する病理組織像が認められ(図 5 ), 頸部結核性 リンパ節炎と骖断された。このため SM，INH，REPの 了者併用療法を施行した。上咽頭癌に対しては adjuvant chemotherapy としてPTP 療法(術前化学療法と同 等量)を施行した。その後の経過観察では平成 7 年 4 月

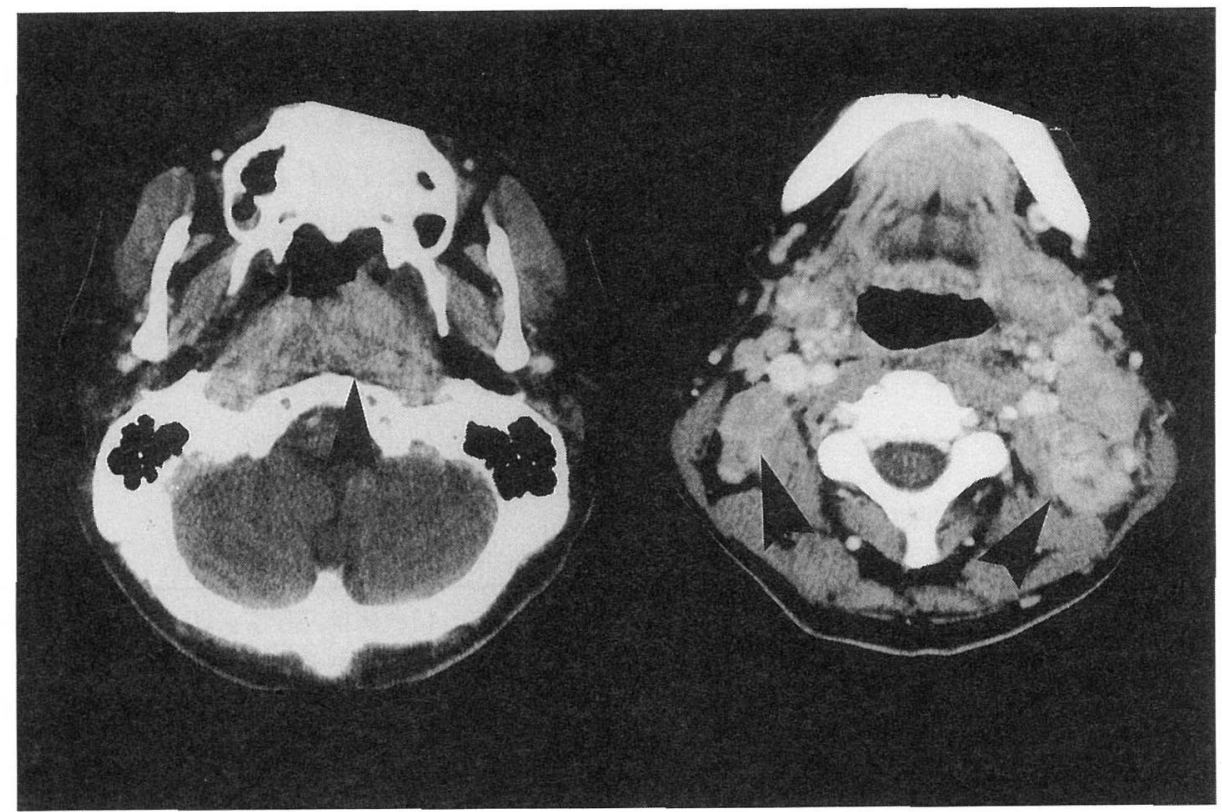

図 3 症例 2 の頸部 CT スキャン

左：上咽頭後壁を中心に造影剂により増強される腫瘍を認める(矢頭). 右：両側頸部に造影剤で増強されるリンパ節を多発性に認める(矢頭). 


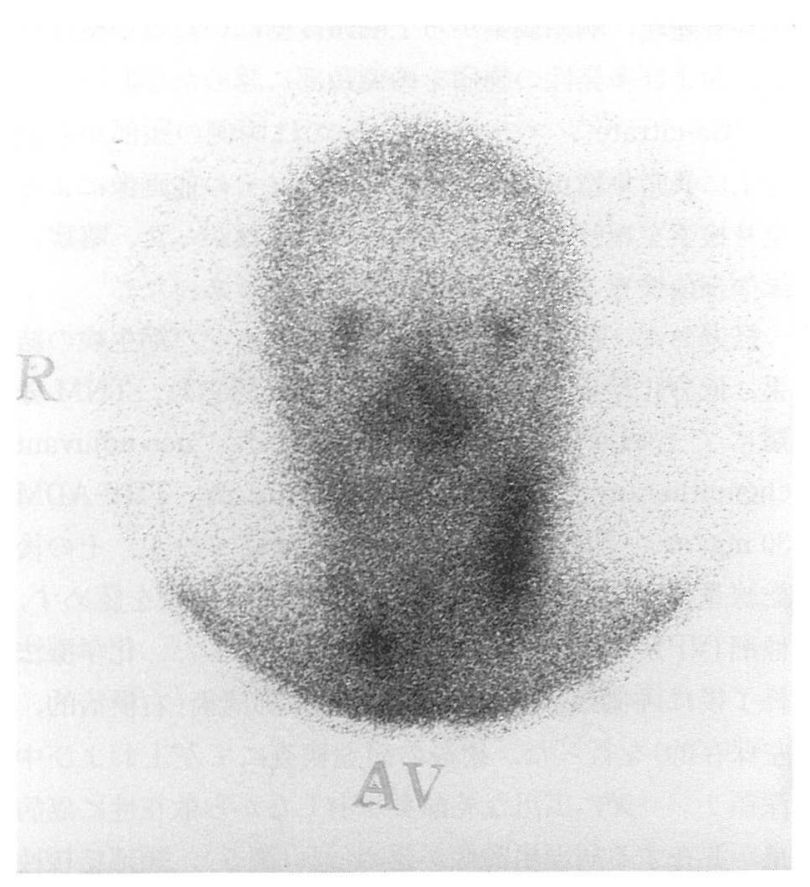

図 4 症例 2 の ${ }^{67} \mathrm{Ga}$-citrate シンチグラフィー左下顎から左頸 部，扣よび右頸部から右鎖骨上にかけて異常集積が認め られる(48時間後).

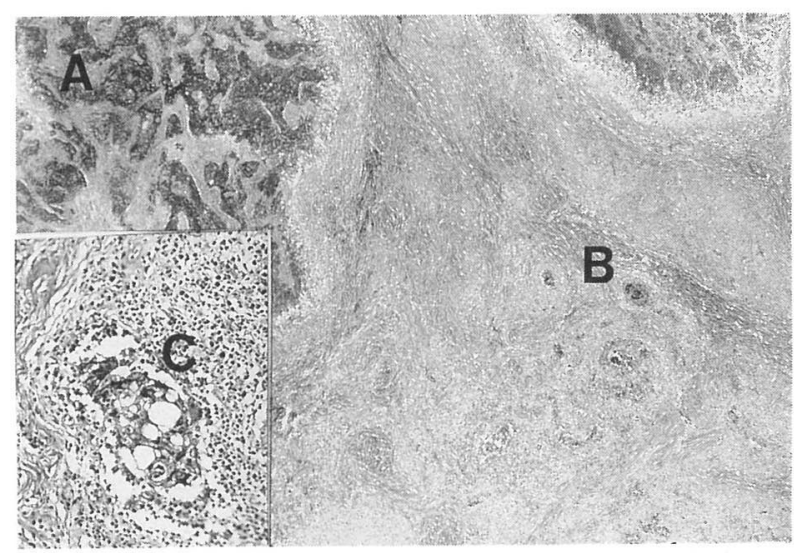

図 5 症例 2 の病理組織学的所見 (H.E. 染色 弱拡大 $\times 100$, 強挔大 $\times 400$ )
A. 乾酪壊死
B. 癌胞巣
C. 癌胞巣の強拡大

まで再発なく順調に経過している.

\section{考察}

結核と悪性腫瘍との関係については，両者は拮抗し合 い，共存しにくいとの説2)が長く支持され，このことが
BCG による悪性腫瘍の治療の 1 つの根拠ともなってき た ${ }^{3)}$. しかし，悪性腫瘍と結核の合併症例の報告も

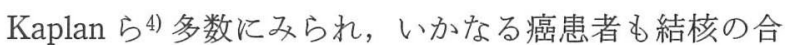
併があり得ると述べている5)6). Raman ら ${ }^{7)}$ は口蓋部の 活動性結核病巣中に発生した腫瘍の 1 例を報告し, その 中で結核之悪性腫瘍との共存様式を表 1 の上うに分類し ている. 今回の症例 1,2 は, 発生場所については A-3), 発生時期飞関しては B-2) あるいは B-3) 飞相当するも のと考兄られた。 しかし, これらの報告当時と現在の結 核の罹患率の差や結核症例の多くが活動性肺病变であっ た事を考慮すると，頸部結核性リンパ節炎と悪性腫瘍の 合併の頻度は少ないものと思われる。特に, 頭頸部領域 の癌と肺病変を伴わない頸部結核性リンパ節炎の併発は, 本邦に领いては大石ら ${ }^{8)}$ 数例の報告のみである.

癌患者の結核の発症因子として, 担癌患者の細胞性免 疫の低下, 特に上咽頭癌に括いては, 早期より極度の免 疫能の低下が示唆される9). 今回の 2 症例も初診時より $\mathrm{CD} 4 / 8$ 值の著しい低下が認められた。 このため初感染 し発症せずに潜んでいた結核菌が再燃した可能性が強く 疑われ，さらに上咽頭癌に対寸る化学療法や放射線照射 等の集学的治療により, 宿主の細胞性免疫能が一層低下 したため結核が増悪したと推察される。 また, Kaplan ら）によると癌患者へのステロイド使用が結核の増悪 に深く関与して括り，その予後は極めて深刻であったと 報告されている. 本症例 1,2 とも CDDP 使用時飞制吐 作用の目的にてステロイドも使用して拈り, 本剤使用に 際して十分な注意が必要であるう。

今回の症例では頸部郭清後に喀痰培養, 画像による全 身検索を再度行ったが，他臓器への結核の感染は認めら れなかった。しかし，外科切除前に抗結核剤の投与され ていない症例は再発し易い10)といら報告も方り,さら

表 1 Raman $5^{7)}$ の分類

\footnotetext{
A-1）結核病巣と腫瘍病巣とが異なる蔵器にあるもの

A-2) 結核病巣と腫瘍病巣とが同一臓器にあるもの

A-3) 結核病巣と腫瘍病巣とが, 組織病理診に拈いて同 一視野に認められるもの

B-1）結核病变が最初に起こり, 腫瘍発生が続いて起こ るもの

B-2）腫瘍発生が最初に起こり, 結核病変が続発するも の

B-3 ) 結核病変と腫瘍発生が同時期に起こるもの
} 
に術後の化学療法等により細胞性免疫が低下し憎悪する 可能性が示唆され抗結核剤の投与を行った.

頸部結核性リンパ節炎の診断については Cantrell ら ${ }^{11)}$ は以下の診断基準を提唱している.すなわち，(1)頸部腫 瘤, (2)ツベルクリン反応陽性, (3)病理組織で乾酪性肉芽 (caseating granuloma) の存在, (4)生検材料で抗酸菌の 証明，(5)生検材料からの培養で結核菌の証明，(6)抗結核 剤よる化学療法に反応する. これらのらち 3 項目以上該 当すれば頸部結核性リンパ節炎と診断して差し支えない と述べている. 今回の 2 症例では, 残念ながら手術材料 で抗酸菌の証明, あるいは培養にて結核菌の同定が不可 能であったが，上記(1)，(2)，(3)の 3 項目が該当したため 頸部結核性リンパ節炎と診断した。

当施設では肺結核の既往を認める頭頸部悪性腫瘍症例 に対しては, その治療に際し結核の再燃を厳重に注意し てきた，しかし，本症例の様に結核の既往がなく，異常 な胸部陰影を認めない症例については, 十分な経過観察 がなされてきたとは思われない，過去に肺結核の既往歷 のない頸部結核性リンパ節炎の症例が全体の $2 / 3$ 亿認め られるとの報告12)もあり，頭頸部悪性腫瘍の治療にお。 いて，常に頸部結核性リンパ節炎発症の可能性があるこ とを念頭に括いて，頭頸部癌治療を行らべきであろう。

\section{まとめ}

1 ）上咽頭癌に頸部結核性リンパ節炎を併発した 2 症 例を経験した。

2） 2 症例ともに頸部リンパ節の病理組織標本におい て, 結核病巣と癌転移巣が混在する稀な病理所見を得た。

3 ）上咽頭癌による細胞性免疫の低下が発症の誘因と して示唆された.

本論文の要旨は, 第18回日本頭頸部腫瘍学会(平成 6 年 7 月, 札幌)に扮いて発表した。

\section{文献}

1 ）澤木修二：上咽頭癌の腫瘍免疫学的研究. 日医会誌 89 : 721 728, 1983.

2 ) Watoson WL : Lung Cancer. pp 8, Mosby, Saint Louis, 1968.

3 ）中村憲二, 李 龍彦, 中元賢武, 他 : 肺結核病棟に扮ける 肺癌. 結核 $56: 403 \sim 406,1981$.

4) Kaplan MH, Armstrong D and Rosen P : Tuberculosis complicating neoplastic disease. A review of 201 cases. Cancer $33: 850 \sim 858,1974$.

5 ) Feld R, Bodey GP, Groschel D : Mycobacteriosi in patients with malignant disease. Arch Intern Med 136:67 $\sim 70,1976$.

6 ）福重潤一郎, 丸山孝一, 川上 浩, 他 : 悪性腫瘍患者の結 核症. 癌の臨床 $32: 234 \sim 240,1986$.

7 ) Raman R, Kuruvilla A and Bakthaviziam A : Carcinoma of the palatine tonsil co-existin with tuberculosis. J Laryngol Otol 93 : 927 931, 1979.

8 ）大石公子, 鵜飼幸太郎, 板倉康夫, 他 : 当教室 12 年間の頸 部リンパ節結核の臨床統計的観察.耳鼻臨床 $79: 609 \sim 616$, 1986.

9 ）佃 守, 玉虫 昇, 持松いづみ, 他 : 上咽頭癌患者の細 胞性免疫能. 日耳鼻 $89: 7 \sim 13,1986$.

10）中島由梘, 田中一成，守 純一，他 : 頸部結核性リンパ節 炎の外科. 結核 $56: 319 \sim 325,1981$.

11) Cantrell RW, Jensen JH and Reid D : Diagnosis and management of tuberculous cervical adenitis. Arch Otolaryngol $101: 53 \sim 57,1975$.

12）亀田和彦, 植田 豊, 大塚順子, 他 : 頸部リンパ節結核の 検討. 結核 $60: 59 \sim 64,1985$.

$$
\left(\begin{array}{l}
\text { 原稿受付 : 平成 } 7 \text { 年 } 6 \text { 月 } 9 \text { 日 } \\
\text { 原稿採択 : 平成 } 7 \text { 年 } 8 \text { 月 } 9 \text { 日 } \\
\text { 別刷請求先 : 金子卓爾 } \\
\text { 干 } 216 \text { 川崎市宮前区菅生 } 2-16-1 \\
\text { 聖マリアンナ医科大学耳鼻咽喉科学教室 }
\end{array}\right)
$$

